\title{
Introduction: Hegel, Wittgenstein, Identity, Difference
}

We cannot but begin this volume with Wittgenstein's famous remark that "Hegel seems to me to be always wanting to say that things which look different are really the same. Whereas my interest is in showing that things which look the same are really different." (MDC: p.157) This is, however, a casual remark, and it seems that we should not put too much emphasis on it. (For a discussion of how the remark should properly be understood, see Chapter 20.) In compiling this collection of essays we adopted from this remark the idea that the problem of difference in identity is the common topic between Hegel and Wittgenstein. ${ }^{1}$ The remark presents a certain interplay (or, one might say, dialectics) of identity and difference. And it is questions of identity and difference between Hegel and Wittgenstein (with respect to certain aspects of their works, under certain interpretations, etc.) that are addressed by the essays in this volume.

There are systematic reasons for investigating commonalities and differences between two philosophers: for example, that they approached the same problem or topic using the same or different methods and arrived at the same or opposed conclusions. Such an investigation might be conducted ahistorically, without taking into account possible lines of influence. This would, however, contradict Hegel's and Wittgenstein's philosophical doctrines. Before we set about looking at particular points of identity and difference discussed in this volume, let us look at the philosophical and historical context of this topic.

\section{Analytic-continental split}

One of the reasons for bringing Hegel and Wittgenstein together is to overcome or even go beyond what is known as the "analytic-continental split". ${ }^{2}$ As is well known, at the beginning of the 20th century Russell and Moore, the founding fathers of analytic philosophy, revolted against Hegelianism. Analytic philosophy

1 For the sake of brevity, throughout this introductory chapter I shall use names of thinkers, particularly Hegel and Wittgenstein, metonymically, with the names standing for their philosophical thought and the works where their thought is expressed.

2 The analytic-continental split has been addressed in many different ways (cf. Bell et al. (2016) for a representative sample of recent debates). 
became an explicitly anti-Hegelian philosophical movement (cf. Chapter 1 of this volume). Moreover, Hegel's writings were declared to be examples of nonsense, of nonsensical combinations of letters and words. No dialogue is possible with nonsense. On the other hand, continental philosophy (from Marxism to existentialism and structuralism) endorsed, albeit quite selectively, some Hegelian terminology, approaches, doctrines and arguments (cf. Nuzzo 2010: p.3).

All this, however, has turned out to be a myth rather than an accurate description of the philosophical landscape of the 20th century. Moore and Russell revolted against British idealism, which drew on a specific interpretation of some Hegelian doctrines but was opposed to Hegel in some respects. Continental philosophy was, in several important respects, very much opposed to Hegel or Hegelianism (we could mention, say, Heidegger or Adorno). To identify continental philosophy as Hegelian in essence is, to say the least, problematic.

To situate Wittgenstein within analytic philosophy seems to be less problematic. Wittgenstein's Tractatus is without doubt one of the canonical texts of analytic philosophy. Things get complicated with Wittgenstein's later philosophy. Some of the key insights brought up in the Philosophical Investigations (e.g., meaning as use, the private language argument, the critique of ostensive definition) were later taken up in ordinary language philosophy and by analytic philosophers such as Quine, Davidson and Sellars. There are, however, other no less important insights and aspects in Wittgenstein's later thinking that are opposed to mainstream analytic philosophy, such as his conception of philosophy as therapy, his anti-naturalism and the fragmentary style of his writing.

Hence, Hegel's philosophy does not quite belong to continental philosophy and Wittgenstein's (later) philosophy does not quite belong to analytic philosophy, although there are non-empty intersections in both cases. If any points of contact between Hegel and Wittgenstein are of relevance to the analytic-continental split, then it must be ones along these intersections. Several chapters in this volume (Stekeler-Weithofer's, Rentsch's, and Chiurazzi's) address the complicated relevance of Hegel and Wittgenstein to the analytic-continental split, as well as the possibility of overcoming it.

\section{The story of the Hegel-Wittgenstein affinity}

It is not the case that Wittgenstein has been discussed only in analytic philosophy and Hegel only in continental philosophy. Whereas Wittgenstein reception in continental philosophy is not so significant (although see Chiurazzi's and Haas's chapters in this volume, which take broadly continental perspectives), there has been an increasing interest in Hegel and Hegelian themes in analytic philosophy 
since the 1990s, which has brought Hegel closer to Wittgenstein. It is not difficult to find remarks in Hegel that to some extent capture the essence of analytic philosophy. He wrote in the preface to the second edition of the Science of Logic that: "The forms of thought are first set out and stored in human language" (SL 2010: p.12; written in 1831, a few days before Hegel's death). Before examining this renewed interest in Hegel in the 1990s, let us go back to two important philosophers who approached our topic in surprising depth.

John Niemeyer Findlay (1903-1987) was initially a Hegelian scholar. Later, in the 1930s, he was a student of Wittgenstein in Cambridge. Eventually, he turned back to Hegelianism and became a fierce critic of Wittgenstein's philosophy and influence. His books Hegel: A Re-examination (1958) and Wittgenstein: A Critique (1984) were written with full knowledge of both philosophers. The major parallel that Findlay identified between the conceptions of philosophy in Hegel and Wittgenstein is as follows:

Wittgenstein says: "Philosophy is a battle against the bewitchment of our understanding through the instruments of our speech.” [PI: §109] Hegel says in highly similar language: "The battle of Reason consists in this, to overcome the rigidity which the Understanding has brought in.” [EL 1830: §32] ${ }^{3}$

The crucial point of this parallel is the implicit assumption that Hegel and Wittgenstein used "understanding" (Verstand) in a more or less similar way ("in highly similar language”). Findlay was, of course, aware of this complex issue (cf. 1958: pp.62-3). For both Hegel and Wittgenstein, philosophical language consists of exaggerations of ordinary language. Yet philosophical exaggerations "will have 'gone back', much as the various colours vanish and annul each other in the integrity of white light" (1958: p.27). There is one major difference, however, which appertains to the final goal of this philosophical method:

[W]hile for Wittgenstein philosophical exaggerations disappear in this final ordinariness, and need not, except for a confusion, have emerged at all, for Hegel their emergence is essential to the final result, and is in some sense "preserved" in it. (ibid.)

3 Findlay 1958: p.27. In his foreword to Hegel's Logic (1973), Findlay uses a slightly different wording: "Hegel anticipates even the ring of certain pronouncements of modern linguistic philosophy: where Wittgenstein makes it the task of the linguistic philosopher to cure the bewitchment of the understanding through the instruments of our speech (Philosophical Investigations, $\S 109$ ), Hegel says that 'the battle of reason is the struggle to break up the rigidity to which the understanding has reduced everything', the understanding being the form of thought which continues to apply rigid rules and categories, which apply well in ordinary finite contexts, to the new, fluid, iridescent contexts and objects of Reason.” 
It is noteworthy that there is no consensus within contemporary Wittgenstein scholarship as to the goal of his philosophical method. There have been interpretations of Wittgenstein's philosophy stressing that the unspeakable remains preserved in the final result. ${ }^{4}$

Two chapters in this volume discuss Findlay's work. In Chapter 9, Paul Redding focuses on Findlay's critique of the Tractarian conception of simple objects from Hegel's point of view. Karl-Friedrich Kiesow, in Chapter 21, addresses Findlay's discussion of personal pronouns in Hegel and Wittgenstein.

David Lamb, in two book-length studies $(1979,1980)$ and other shorter works, made a heroic attempt to bring Hegel and Wittgenstein closer to each other. At the end of the 1970s, Wittgenstein's later philosophy was at the height of its dominance in analytic philosophy. Lamb's aim in showing similarities between Hegel and Wittgenstein was twofold: to “reveal that Wittgenstein's contribution is not such a break with the past as many of his disciples would have us think" (1980: p.xiii) and to "render Hegel intelligible to the twentieth-century perspective" (ibid.). According to Lamb, the basic parallel between Hegel and Wittgenstein is that they both move from a critical to a descriptive philosophy. The point of departure for Hegel's move is Kant's transcendental philosophy, whereas Wittgenstein moves from his early philosophy to his later thinking:

Of particular concern will be the move from a critique of language (Tractatus) to a description of its use (Blue and Brown Books, and Philosophical Investigations) by Wittgenstein, which is in many ways parallel to the move from a Kantian critique of reason to Hegel's phenomenological description of the various shapes of consciousness in the Phenomenology. (1980: p.5)

Lamb thus interprets the Tractatus as a Kantian work that aims to delineate $a$ priori limits of thinking and define the essence of language (the general form of propositions), which parallels Kant's attempts to locate the foundation and scope of human knowledge. Lamb finds in Wittgenstein's later philosophy "many of the old idealist arguments in a new form" (1979: p.xi).

4 Wittgenstein writes in the Tractatus that philosophy "will mean the unspeakable by clearly displaying the speakable” (4.115, Ogden/Ramsey's trans.). Furthermore, what Wittgenstein wrote about Uhland's poem “Count Eberhard's Hawthorn” seems equally true of the early Wittgenstein's ideal of philosophical writing: "This is how it is: if only you do not try to utter what is unutterable then nothing gets lost. But the unutterable will be-unutterably-contained in what has been uttered!” (Engelmann 1968: p.7 [9 April 1917]) 


\section{The Sellarsian reception of Hegel through Wittgenstein}

Richard Rorty (1997: p.8) once spoke in this connection of "an attempt to usher analytic philosophy from its Kantian to its Hegelian stage”. ${ }^{5}$ Paul Redding (2007) speaks of the return of "Hegelian thought" in analytic philosophy, Tom Rockmore (2001) of the "Hegelian turn" and Angelica Nuzzo (2010: p.2) of a “Hegel-Renaissance”. Following Rockmore (2001: p.360), I would like to highlight that Hegelian themes relevant in analytic philosophy are, for the most part, also Wittgensteinian themes; they lie at the above-mentioned intersection.

Hegel reception in analytic philosophy goes back to Sellars' critique of the myth of the given and his quite selective interest in Hegel. A critique of what Sellars labels the myth of the given, that is, the myth of direct or unmediated epistemic access to given sensory experience, can be found in the "Sense-Certainty" chapter of Hegel's Phenomenology and in Wittgenstein's critique of ostensive definition at the beginning of his Philosophical Investigations. Despite many differences, Hegel's and Wittgenstein's arguments boil down to the fact that seemingly direct pointing at sensory experience (to "this" and "now") presupposes complex cognitive or grammatical structures. ${ }^{6}$

There are other Hegelian insights that Sellars introduced to analytic philosophy. Let us mention another important one: Hegel's key claim that "everything is an inference" became the cornerstone of contextualism and inferentialism. "Everything" must be understood here in the context of Hegel's logic as “every judgement". The truth of a judgement is thus dependent on its place within a syllogism or, in contemporary terms, its role in an inferential structure or the normative space of reasons. This is also a Wittgensteinian insight, for the concept of inferential structure is close to the later Wittgenstein's concept of language-games (more specifically: the language of giving and asking for reasons,

5 One can speculate what the next "phase" of analytic philosophy will be. Perhaps a Marxist one or even a "Deleuzian turn" as suggested by Lumsden (2011).

6 This is not to say that the myth of the given can be attacked only from a Hegelian or a Wittgensteinian perspective, as Donald Davidson's critique of the myth proves.

7 "Alles ist ein Schluß” (E I: §181); other translations are "everything is a syllogism” (EL 1830/ 2010: p.254) and "all things are a syllogism" (SL 2010: p.593). To translate Schluß as mere "inference” is already a move towards Sellars' and Brandom's interpretation of Hegel's logic. Di Giovanni also translates Schlu $\beta$ as "syllogistic inference" (ibid.), which is probably a more accurate translation. 
in Sellars' and Brandom's case). ${ }^{8}$ Ultimately, we can understand Hegel's slogan "Everything is an inference" as affined to Wittgenstein's "Meaning is use".

Like most previous Hegel reception, Sellars' reading of Hegel is quite selective. He incorporated some Hegelian topics into his system, while ignoring others; moreover, Sellars' system is party openly anti-Hegelian. Sellars (and Brandom) ignore Hegel's main concept of self-consciousness. His system ignores Hegel's idealism and, in the end, he endorses linguistic nominalism, epistemic empiricism and metaphysical realism, which are all anti-Hegelian doctrines. Sellars was no Hegelian, nor was he a Wittgensteinian. Rather, he took important impulses and developed themes that fall within the intersection of Hegel's and Wittgenstein's thinking.

Before moving on to the "Pittsburgh Neo-Hegelians", John McDowell and Robert Brandom, ${ }^{9}$ let us mention Pirmin Stekeler-Weithofer's book Hegels Analytische Philosophie: Die Wissenschaft der Logik als kritische Theorie der Bedeutung (1992), which anticipates many central insights of Brandom's inferentialism and his semantic interpretation of Hegel.

McDowell (1996) focuses on the Kantian roots of Sellars' philosophy and shows why it is necessary, for Sellars and for analytic philosophy in general, to go beyond Kant's transcendental idealism towards Hegel's absolute idealism. McDowell develops Sellars' critique of the (doctrine of) givenness and argues that the structure that must be presupposed in any given experience is best conceived as the Aristotelian substance. McDowell, however, insists on Sellars' empiricism, which does not contradict his minimally or non-standard empiricist interpretation of Hegel. ${ }^{10}$ The idea is that it is a mistake to interpret either Kant's or Hegel's idealism as lacking empirical constraints on knowledge: that is, mental events and perceptual experience can be justifications for beliefs. Then, however, Sellars' critique of the myth of the given rests, in McDowell's view, on a mistaken interpretation of Hegel. In this context, McDowell's Hegel can be deployed against analytic criticism of empiricism, which includes the later Wittgenstein (cf. Rockmore 2005: p.147).

8 On the analogy between Wittgenstein's language-games and Sellars' space of reasons, see Sellars (1954) and Rockmore (2005: p.145). Furthermore, Koreň and Kolman (2018: p.31) conceive Wittgenstein's concept of language-game as Hegelian.

9 McDowell and Brandom are not the only ones who have developed Sellars's WittgensteinianHegelian legacy. Terry Pinkard's book Hegel's Phenomenology: The Sociality of Reason (1994) appeared in the same year as Brandom's Make It Explicit and McDowell's Mind and World. However, Pinkard's focus is primarily on Hegel with only passing references to Wittgenstein.

10 Cf. Rockmore (2005: p.146) and Redding (2007: p.24). 
In contrast to Sellars' and McDowell's selective reception of Hegel, Brandom attempts to provide a genuine reading that he calls the semantic interpretation, which allows him to assimilate Hegel into the analytic tradition in the wake of the "linguistic turn". Brandom describes his programme as "inferentialism". He contrasts it to "representationalism", which is indebted to the myth of the given (cf. Rockmore's discussion of representationalism in Kant and the early and later Wittgenstein in Chapter 3). Following Koreň and Kolman (2018: p.1) we can define inferentialism in a narrow and a broad sense. ${ }^{11}$ In the narrow sense, inferentialism is a doctrine in the philosophy of language that takes linguistic meaning as being grounded in an inferential structure (and not the other way around). In the broad sense, it is an epistemological doctrine that gives the concept of inference a privileged explanatory role. In both senses, inferentialism is motivated by Hegel's above-mentioned slogan: "everything is an inference". The concept of inference is related to Hegel's concepts of "determinate negation" and "mediation", which Brandom interprets as "material incompatibility" and "material consequence" (where mediation/material consequence can be defined in terms of determinate negation/material incompatibility). ${ }^{12}$ As already mentioned, the concept of inferential structure also has roots in Wittgenstein's concept of a language-game. But Brandom deliberately restricts Wittgenstein's plurality of language-games into a single, most fundamental game, namely the rationalistic and normative game of reason-giving (cf. Koreň and Kolman 2018: p.39). Wittgenstein, in contrast, does not give priority to any particular language-game. Brandom is also critical of Wittgenstein's negative attitude towards philosophical theories and sides instead with Hegel's constructivist approach and system-building (Brandom 2014: p.7). Consider Brandom's schematic view of Wittgenstein's philosophical development: “we can see the Wittgenstein of the Tractatus as a neo-Kantian, without Kant's residual empiricism, and the Wittgenstein of the Investigations as a neo-Hegelian, without Hegel's revived rationalism." (Brandom 2014: p.4) Brandom is, then, a neo-Hegelian with Hegel's rationalism and a Wittgensteinian without Wittgenstein's anti-rationalism. Several of the papers in this volume address and critically evaluate Brandom's Hegel; see Shaheen's, Redding's and Kolman's chapters.

11 Not to be confused with Brandom's broad and narrow conception of inferentialism (1994: p.131).

12 Cf. Brandom (2014: p.11). 


\section{Major interpretative approaches in Hegel and Wittgenstein scholarship}

Both Hegel and Wittgenstein scholarship have become philosophical subdisciplines in their own right. There have been diverse and often mutually exclusive interpretations of both thinkers. It is not surprising that these interpretations follow various aims and methodologies and place emphasis on different aspects, such as exegetical accuracy, charity, the viability of a given philosophical position or compatibility with other, earlier or later philosophical views and theories. Bringing together and comparing Hegel and Wittgenstein is, then, often relativized to this or that interpretation; a certain interpretation of Hegel is compared with a certain interpretation of Wittgenstein. The authors in this volume are not only aware of these complications, but work creatively with them. In this section, I want to outline the major interpretative approaches to Hegel and Wittgenstein, and briefly discuss their possible compatibilities and irreconcilabilities. I shall only mention the interpretative approaches that are represented in this volume.

The reception of Hegel's thinking has been marked by (at times very creative and productive) misunderstandings and (at times quite deliberate) misinterpretations. ${ }^{13}$ Many readings have focused solely on one of his works or taken one aspect of his system, one "shape of consciousness" or one particular concept (the master-servant dialectic, the unhappy consciousness or plasticity). Such interpretations are not without importance, but I will focus only on those approaches to Hegel that attempt to interpret his system as a whole. As one would expect, there is no accepted way of classifying these interpretations. I shall combine two recent overviews of Hegel scholarship by Terry Pinkard (2013) and Paul Redding (2015).

The traditional metaphysical or Neoplatonic view takes Hegel's philosophy as a kind of rational theology. The Absolute Spirit is like the Neoplatonic or Christian God. Various stages of Hegel's dialectic, notably various shapes of consciousness presented in the Phenomenology, are interpreted as emanations of this God. Many of Hegel's claims and formulations support this view, e.g., his invoking the concept of God in the preface to the Phenomenology or later claiming that "philosophy has no other object but God and so is essentially rational theology” (LA: p.101). Representative advocates of this view are Taylor (1975)

13 This might also be said of Hegel himself in relation to his reception of his predecessors and contemporaries. 
and Beiser (2005), as well as the German scholars Heinrich (1971), Horstmann (2006) and Siep (2014).

There are revised or realist variants of the metaphysical view, mostly Aristotelian (Stern 2002, Westphal 2003 and, in certain respects, McDowell 2009), but also Spinozist (Houlgate 2005) or Platonist. It is essential for this view that reality is inherently rational or conceptually structured. The concept is the fundamental structure of thinking as well as reality. This is true also for the traditional view, but the revised metaphysical view does not attribute to Hegel the robust teleological spirit monism attributed by the Neoplatonic interpretation.

The third group of interpretations takes Hegel to be carrying out, extending and eventually completing Kant's critique of (traditional) metaphysics. There are many varieties of this post-Kantian view. Some of them, notably those of Pippin (2005), Rockmore (1997), Pinkard (1994) and Gabriel and Žižek (2009), explicitly interpret Hegel in this post-Kantian fashion. Brandom's semantic interpretation and inferentialism and McDowell's interpretation are also broadly post-Kantian (although McDowell, in contrast to Brandom, is committed to Aristotelian realism). Another strand of this post-Kantian view comprises analytic-pragmatic interpretations, for instance Stekeler-Weithofer (2016).

Finally, there is the view that Hegel's philosophy does not aim to present any (first-order) metaphysical theory, but is rather a meta-critique or a meta-metaphysical critique of any metaphysics. The most explicit formulation of this view is in Gabriel (2016: p.185): "Hegel's absolute idealism is not a first-order metaphysical view about the composition of ultimate reality [...]. Rather, it is a defence of the meta-metaphysical idea that there are different kinds of facts [...] which share a logical structure that guarantees their overall intelligibility." We can already find an inclination towards this meta-metaphysical view in Findlay (1958), and more recently in Redding (2017), who focuses on Hegel's category of actuality (Wirklichkeit), which includes possibility and necessity as abstractions (cf. Cammi's realist view of Wirklichkeit in Chapter 7). Hegel's metaphysics is, thus, a form of modal actualism that includes first-order metaphysical theories as abstractions. This view is not necessarily in conflict with the post-Kantian interpretation (for there are meta-metaphysical aspects in Kant too). There is a milder version of this view which holds that Hegel provides meta-metaphysical arguments compatible with the realist view. ${ }^{14}$

14 Here is an apt formulation of this view: Hegel dismisses "the question concerning whether metaphysics tout court is possible, and [insists] on asking the 'real' meta-metaphysical question: 'What kind of metaphysics is the right kind of metaphysics?'” (Giladi 2016: p.157) Giladi, however, concludes that Hegel's metaphysics is "a sophisticated melange of Aristotelianism, Spinozism, Kantianism and post-Kantian philosophy of nature” (ibid.: p.159). 
Let us turn now to the labyrinthine world of Wittgenstein scholarship, which in its baroque exuberance exceeds even Hegel studies. Two major interpretative disputes will be presented here. The first is the dispute between the traditional (or metaphysical/irresolute/theoretical/Tolstoyan) and therapeutic (or New/resolute/liberatory/dialectical/Kierkegaardian/Cavellian) readings of Wittgenstein's philosophy, predominantly of the Tractatus (but also of later texts).$^{15}$ For obvious reasons it is useful to characterise these two groups of readings according to their attitude to the Kantian programme of delineating the limits of knowledge. On the traditional view, Wittgenstein provides in the Tractatus a broadly Kantian argument that aims to delineate the limits of language. ${ }^{16}$ On the therapeutic view, Wittgenstein is combating our natural desire for such an argument or for metaphysics in general. The traditional view stresses the many logical, metaphysical and epistemological insights expounded in the Tractatus; the therapeutic view, in contrast, insists on the analogy with the ladder presented in the closing remarks of the treatise, which proclaim the sentences that make it up to be nonsensical. These sentences serve as elucidations and must eventually be discarded, just like "the ladder after he has climbed up it" (TLP: 6.54). This dispute can be extended to or transposed onto Wittgenstein's later philosophy. The difference is, however, that there is no main or central argument to be identified there, but rather several, more or less interconnected arguments which the traditional view concentrates on. The so-called private language argument is the most famous one.

This brings us to the second main dispute, namely the debate over rules, private language and scepticism between Saul Kripke (1982) and his opponents. The conclusion of the private language argument (PI: §§244-271 and elsewhere) seems to be that a language intelligible solely to its originator (i.e., a private language) is ultimately unintelligible to this very language user. In other words,

15 Cf. Crary and Read (2000), the manifesto for the therapeutic view, and a good exposition of recent debates in Read and Lavery (2011).

16 Cf. Floyd (2007: p.177): "The most fundamental divide among interpreters of Wittgenstein lies [...] between those who detect in Wittgenstein's writings some form of semantic or epistemic resource argument, an argument ultimately appealing to the finitude or expressive limitations of language-whether it be truth-functional, constructivist, social-constructivist, antirealist, assertion-conditionalist, formalist, conventionalist, finitist, empiricist, or what have you-and those who instead stress Wittgenstein's criticisms of the assumptions lying behind the desire for such resource arguments, criticisms that in the end turn upon stressing the open-ended evolution, the variety, and the irreducible complexity of human powers of expression. The former kind of reader sees the inexpressible as a limitation, a reflection of what is illegitimate in grammar or fails to be epistemically justifiable; the latter sees the inexpressible as a fiction, an illusion produced by an overly simplified conception of human expression.” 
there is no private language, or language is essentially social. Kripke argues that this argument is actually a corollary of a more general paradox concerning rulefollowing: "This was our paradox: no course of action could be determined by a rule, because every course of action can be brought into accord with the rule." (PI 2009: §201) This is, for Kripke, a sceptical paradox Wittgenstein was facing and attempting to overcome. Kripke's solution to this paradox rests on the requirement of community agreement (which is why his position is known as the "community view").

The opponents of the community view either deny that Wittgenstein is dealing with scepticism in these passages ${ }^{17}$ or they accept the charge and present different solutions. There are two prominent alternatives: the disposition view (speakers grasp a rule due to their dispositions to apply the rule in novel situations) and primitive non-reductionism (a speaker's grasp of a rule is a primitive mental fact about the speaker). ${ }^{18}$

Where does this very brief overview of recent interpretations of Hegel and Wittgenstein leave us? Only a few connections between the two can be discussed here. The traditional metaphysical view of Hegel and the traditional view of Wittgenstein can be brought together, as in Rentsch's, Lütterfelds's and Kleber's chapters. Lamb's proposal to interpret Wittgenstein's early works in a Kantian manner and Wittgenstein's later works in a Hegelian manner is possible only on the traditional view of Wittgenstein and the post-Kantian view of Hegel. This interpretative strategy is advanced in Haas', Chiurazzi's and Pinkard's chapters (Pinkard also considers the resolute reading). Redding addresses the traditional and therapeutic readings of the Tractatus together with the post-Kantian reading of Hegel, but eventually turns to Findlay's modal actualism. Brandom's post-Kantian semantic interpretation of Hegel draws on the community view of Wittgenstein (cf. Kolman's and Shaheen's chapters), while McDowell's Wittgenstein is openly against the community view. The realist view of Hegel can be compared to the traditional metaphysical interpretation of the Tractatus (as in Cammi's chapter). Rockmore interprets Wittgenstein, in his chapter, as "either a metaphysical realist or an epistemic skeptic", that is, he invokes both the traditional and sceptical views. Pluder considers the community view of rule-following in relation to Hegel's ethics and ethical life. Balestracci draws on the thera-

17 Cf. Baker and Hacker (1984). Advocates of the resolute view would also deny that Wittgenstein is advancing any argument here or elsewhere.

18 For the disposition view, see for example Horwich (1984); for primitive non-reductionism, see for example McDowell (1984). 
peutic reading of the Tractatus and compares it with the dialectics of the Phenomenology of Spirit. Plevrakis adopts the therapeutic view in his Hegelian interpretation of the Tractatus. Moser also interprets the Tractatus within the therapeutic perspective (albeit in a rather unorthodox way), but her account has a strong Kantian accent too. This is only an outline of the interpretative complexities. Let us next turn to the structure and content of the volume in detail.

\section{The structure of the volume and the individual chapters}

How to bring two different philosophers together? As we know from Fichte, ${ }^{19}$ every difference presupposes a common ground, an identity (and every identity presupposes a ground of difference). Both Hegel and Wittgenstein followed Fichte in this respect. Hegel did so when he maintained that everything has a ground and everything is a judgement, ${ }^{20}$ Wittgenstein when he proclaimed self-identity to be nonsensical (for an identity without difference would be a self-identity). ${ }^{21}$

Re-evaluating the differences between Hegel and Wittgenstein, then, will consist either in highlighting their differences against the background of their identity, or in highlighting their common points against the background of their differences. Let us label these approaches "From identity to difference" and "From difference to identity" respectively. The latter approach, "From difference to identity", might be sketched as follows: let us assume that the thinking of these two philosophers is very different (they might have different goals, use different methods and terminology; they might differ in what they take for granted; they might focus on different topics, etc.). And this is prima facie indeed so. Within these differences, however, one might try to find a point of contact and establish whether they agree on some particular issue. The former approach, "From identity to difference", in contrast, begins by establishing a common ground or rather a common background (a presupposition, a topic, a perspec-

19 This is the distinction between a "ground of distinction" (Unterscheidungsgrund) and "ground of relation/conjunction" (Beziehungsgrund) from the third paragraph of Fichte's Science of Knowledge.

20 Hegel claims this at many points, e.g. in his Berlin lectures of 1831 (LL 1831: p.131).

21 Curiously enough, Carlson (2005: p.xi) thinks that the denial of self-identity in Hegel constitutes his fundamental difference from analytic philosophy. If that were so, Wittgenstein's thinking, early and late, would also fundamentally differ from analytic philosophy. 
tive) against which a difference (in the form of a disagreement) between Hegel and Wittgenstein can be established. This passage from identity to difference or vice versa can be embedded in a dialectical process. Any identity (or difference) that is reached is a point of departure for a new passage towards another difference (or identity). So Hegel and Wittgenstein may initially be taken to be very different philosophers; next, a common ground (thesis, perspective, concept) between them is established (identity), but within this common ground, there may be specific differences.

Following this general consideration, we divided the first half of the volume into two main sections, "From identity to difference" and "From difference to identity". We begin our volume with two chapters that are more general in scope, exploring the relevance and sustainability of the analytic-continental split.

Pirmin Stekeler-Weithofer investigates, from a broadly Hegelian perspective, metaphysical commitments of various strains of analytic philosophy, specifically logical atomism, physical atomism, naturalism and materialism. He identifies (sometimes latent) empiricism in these movements and counters with the Hegelian claim that "[s]cience is collective work on concepts, not merely a process of gathering empirical facts". These movements do not understand the socalled "transcendental turn", which Stekeler-Weithofer traces back to Descartes. The materialist/mechanist/objectivist worldview amounts, in the end, to manifestly incoherent metaphysics.

Thomas Rentsch presents, closer to the main topic of this volume, three key hypotheses about Hegel and Wittgenstein: (1) the proposition is the fundamental unit of dialectics/meaning construction, (2) Hegel systematically anticipates the thesis of meaning as use, and (3) we can find the private language argument in Hegel.

The first major section is comprised of chapters that proceed from identity to difference, that is, they take some point of identity between Hegel and Wittgenstein as a (sometimes only implicit) presupposition and then focus on the difference between them.

Tom Rockmore opens his chapter with the observation that both Wittgenstein and Hegel challenge the view that philosophical problems can be dealt with through a theory. They do so, however, in different ways. Although they both aimed to bring the philosophical tradition to its end, for Wittgenstein, philosophy ends in scepticism, while for Hegel this end is, at the same time, the culmination of philosophy, its fulfilment. 
Herbert Hrachovec begins by remarking that both philosophers often approach philosophical problems not head-on, but by discussing (and criticising) established cognitive attitudes. Hrachovec then focuses on their reflections on the ordinary understanding of measurement. He proceeds by "triangulating" Hegel and Wittgenstein vis-à-vis a non-partisan account of measurement that allows one to find an interesting shared concern, namely a shared alertness to a concealed side of standards. It is against this background affinity that some of their differences appear in sharper contrast.

David Kolb's point of departure is the observation that both Wittgenstein and Hegel see our many languages and forms of life as constituted by different diamond nets of categories or grammars. Kolb then proceeds to argue that both Wittgenstein and Hegel take a non-reductive attitude toward this plurality of local ontologies. They disagree, however, about the philosophical implications of this plurality. Their disagreements stem from divergent notions about the structure and mode of being of the diamond nets.

Jonathan Shaheen identifies an analogy or shared concern between Hegel and Wittgenstein. They both give arguments for the social constitution of philosophically central entities. Shaheen focuses on seminal interpretations of these arguments, on Brandom's reading of the self-consciousness chapter of the Phenomenology of Spirit and on the communitarian reading of the private language argument in the Philosophical Investigations. Against this background, several differences are established: first, their different conceptions of mind; second, their different accounts of the relation between time slices of a single mind and genuine social contributions. Shaheen maintains: "Whereas communitarianism buys the Wittgensteinian so little that it can be had for the cost of individual time slices, the sociality Brandom is selling costs so much that the resources it takes to buy it can equally well purchase self-consciousness with no social contribution whatsoever."

Lorenzo Cammi elaborates in great detail on Hegel's and Wittgenstein's notions of Wirklichkeit before attempting a comparison of them. Given Cammi's realist/metaphysical interpretations of Hegel and Wittgenstein, several common points are established, in order to point out important differences. Both Hegel and Wittgenstein were convinced that it is possible to know the world. Yet according to Wittgenstein, some aspects of the world are inexpressible. In contrast to Hegel, Wittgenstein's notion of Wirklichkeit is restricted to empirical facts. Both Hegel and Wittgenstein maintain that reason and the world share the same essence; moreover, reason constitutes Wirklichkeit. Yet in Wittgenstein the constitutive role of reason is passive compared with Hegel. Hegel's conception of the actualisation of the world is dynamic whereas Wittgenstein's is static. 
Kai-Uwe Hoffmann focuses on the concept of beauty. He starts out from similarities between Hegel and Wittgenstein with regard to their critique of scientism and other minor points. Within this common ground, several differences appear: Wittgenstein would reject Hegel's metaphysical, epistemological and scientific claims concerning the concept of beauty.

The second main section groups together chapters that proceed from (sometimes tacit) differences in order to find some common point (identity) between Hegel and Wittgenstein.

Paul Redding begins by remarking that comparing Hegel and Wittgenstein can be a hazardous affair. With this consideration in mind, he attempts to find some specific points of intersection between Hegel and the Wittgenstein of the Tractatus. More specifically, these points of contact are found between Hegel's (positive and negative) existential judgement and Wittgenstein's atomic propositions. After this specific comparison is made, further Hegelian themes emerge in the context of the Tractatus. Hegel and Wittgenstein were both opposed to the practice, common among logicians, of generalising by eliminating singular terms.

Terry Pinkard states at the outset that Hegel and Wittgenstein are an odd pairing: Hegel sought unity and created a forbidding technical vocabulary; Wittgenstein, in contrast, focused on heterogeneity (of language) and aimed at clarity in philosophy. Despite these differences, however, they both shared an interest in the (Kantian) problem of the limits of thought. Furthermore, both Wittgenstein and Hegel rejected Kant's sharp distinction between things in themselves and appearances. And finally, they were both convinced that "in making sense of things, we are inevitably driven to make sense of making sense, to a kind of logic".

Valentin Pluder admits that Wittgenstein and Hegel are very different kinds of philosophers in every respect. His aim is to find a point of contact where they can be compared. This point of contact is their concern with the connection between rules and acts: a mere formal rule cannot establish or cause interpersonal action. This similarity lies in Hegel's critique of Kant's categorical imperative and Wittgenstein's critique of rule-following. Moreover, they also share similar solutions for how to make this connection between rules and acts: there must be some internal relation between a rule and an act. For Hegel, this relation is the ethical life; for Wittgenstein, it is social institutions and forms of life.

Valentina Balestracci aims to investigate whether there can be a connection between Hegel and Wittgenstein. Such connections are found in comparing tautologies and contradictions in the Tractatus on the one hand and speculative 
propositions in the Phenomenology of Spirit on the other. Moreover, Balestracci pursues a deeper analysis of Hegel's speculative propositions, in order to shed light on the much-discussed relation between the Phenomenology and the Science of Logic.

Vojtěch Kolman starts his chapter with the suggestion that Wittgenstein's remark that his and Hegel's philosophies are opposed to each other can be read with Adorno's eyes as a critique of Hegel's "identity philosophy". In this sense, Wittgenstein's and Hegel's. He claims that their philosophies might be easily seen as opposedare, in some important respects, identical or similar to each other. But this difference presupposes another kind of identity, namely an overall commensurability of both philosophies. According to Kolman, this identity consists in the way Hegel and Wittgenstein develop their concepts of knowledge from more primitive forms of consciousness and bring them to a cautiously optimistic closure based on the sociality of reason, particularly as mirrored in Hegel's master-slave parable and Wittgenstein's private language argument.

Ingolf Max compares the beginning of the chapter on "Being" in Hegel's Science of Logic (pure being without further determinations) and the first sentence of Wittgenstein's Tractatus ("The world is everything that is the case"). Although these accounts seem to be different or even opposed to each other, Max finds a striking analogy between Hegel's global identity of pure being and pure nothing and Wittgenstein's world as the total reality. He thus focuses on Hegel's category of contradiction and its Wittgensteinian counterpart.

Marco Kleber asserts at the beginning of his chapter that Wittgenstein and Hegel have opposed views concerning the concept of the unspeakable. For Wittgenstein, the logical form of the world is unspeakable, whereas the immediately given, the fact, can be expressed in language. For Hegel, the immediately given is precisely what is unspeakable. What is revealed in language is the concept, which, according to Kleber's metaphysical interpretation, is the logical form and structure of all reality. Kleber thus speculatively equates Wittgenstein's logical form with Hegel's concept.

The second half of the volume is made up of chapters that aim not at a comparison but at a fresh interpretation of some aspects of Hegel's or Wittgenstein's thinking. Interpretations of one of the two philosophers are inspired by or taken from the perspective of the other. More specifically, these chapters present either a Hegelian interpretation of Wittgenstein's thinking or a Wittgensteinian interpretation of Hegel's thinking (and some, notably Kiesow's chapter, focus on both approaches). These perspectival approaches must presuppose that He- 
gel's thinking is different from Wittgenstein's; they proceed from a difference. A successful interpretation of one of the thinkers through the lens of the other reveals, however, that they have something in common. Interpreting one of the thinkers through the lens of the other is thus a special case of the approach from the previous section, "From difference to identity". We divided this second part of the volume into two sections, "Hegelian approaches to Wittgenstein" and "Wittgensteinian approaches to Hegel". Let us begin with "Hegelian approaches to Wittgenstein".

Aloisia Moser concentrates on Wittgenstein's projection method and its privation, the so-called zero-method. The zero-method is an activity of the mind akin to the "I think" of Kant's transcendental apperception or Hegel's speculative method in logic in which "method is the consciousness of the form of the inner self-movement of the content of logic" (SL 2010: p.33). Drawing on these parallels, Moser concludes that Wittgenstein's philosophical method goes beyond merely pointing out misunderstandings of the logic of our language. Method, in Wittgenstein and Hegel, is something that happens within concepts.

Ermylos Plevrakis attempts to interpret the Tractatus by referring to the reader's thoughts, feelings and understanding, imagining that this reader is Hegel. The core of his interpretation consists in taking the Tractarian "sole logical constant” (TLP: 5.47) as being equivalent to Hegel's concept, as developed in the Science of Logic. Hegel's sole logical constant can be regarded as "something like the missing logical elucidation of Wittgenstein's N-operation"; it is the concept of concept from the very first chapter of the Doctrine of the Concept, the sequence of universality, particularity and singularity.

Gaetano Chiurazzi focuses on Hegel's discussion of Kant's second antinomy in order to show the anti-analytical presuppositions of Hegel's philosophy. He then identifies what he calls the "cosmological antinomy" of the Tractatus, that is, its internal tension between an analytic principle (centred on the concept of simple objects) and a synthetic one (centred on the concept of form). His Hegelian interpretation of the Tractatus brings the logical form closer to the form of life from Wittgenstein's later philosophy. The logical form has "life", or, in Hegelian terms, it has a "soul"; it is, in the end, a concept (as Marco Kleber and, implicitly, Bruno Haas also maintain in their chapters).

Bruno Haas aims, at the outset, to address a group of philosophical problems present in the Tractatus from a Hegelian point of view. He interprets the Tractatus as a treatise on the Being of logic, that is, a treatise aimed at making logical form explicit. Haas focuses on Wittgenstein's remarks on the nature of subjectivity in relation to reference, especially 5.5422, "there is no such thing as the soul", which is, Haas argues, a misleading translation of "die Seele ist ein Unding" that wrongly implies there is no such thing as an Unding. Haas 
then proceeds to provide a general characterisation of Wittgenstein's theory of reference, focusing on its lack of differentiation between logical levels (through the image paradigm). He interprets this lack against the background of Hegel's theory of reference, as developed in his theory of contradiction.

Alexander Berg investigates what Wittgenstein actually said about Hegel and critically evaluates these remarks. Berg considers (openly anachronistically) what Hegel might have replied to Wittgenstein's words about his philosophy: "Wittgenstein seems to think that I always want to say that singular things only get their meaning from the universality. Whereas he himself is interested in showing that we can say this only in particular situations."

The final group of authors aim to make contributions to Hegel scholarship from a Wittgensteinian perspective.

Karl-Friedrich Kiesow starts out from the observation that both Hegel and Wittgenstein were aware of the privileged position of pronouns in linguistic discourse. In order to make a comparison possible, he narrows down his discussion to a critical analysis of the contributions of two distinguished interpreters of Hegel and Wittgenstein, namely, J. N. Findlay and Paul Weiss. Kiesow focuses on Findlay's Wittgensteinian reading of $\$ 184$ of the Phenomenology, where Hegel presents his theory of acknowledgement, and on Weiss's Hegelian reading of $\$ \S 220-1$ of the Zettel, where Wittgenstein examines facial expressions. Findlay adopts a standard of meaningfulness that he erroneously connects with Wittgenstein and, therefore, comes to the conclusion that Hegel fails to capture the normal linguistic usage. Findlay's demand for an existential phenomenology in which the normal usage is restored is met by Weiss, who also justifies the need to explore the system of personal pronouns by submitting them to speculative transformations.

Jakub Mácha provides a distinctively Wittgensteinian interpretation of Hegel's subjective logic, especially the parts on the concept, the judgment and the Schluß. He argues that Wittgenstein implicitly recognised the moments of universality, particularity and individuality. More specifically, the moment of particularity occupies in Wittgenstein the status of a paradigm sample which mediates between a universal concept and its individual instances. Given this interpretation, Mácha provides a generic account of the emergence of concrete universals through a series of negations that follows the basic structure of Hegel's judgement: the individual is the universal.

Wilhelm Lütterfelds, in the sole chapter in German, understands Wittgenstein's late philosophy (taken mostly from On Certainty) as a kind of linguistic idealism. From this perspective, he interprets Hegel's dialectic as an idealist lan- 
guage-game. The most fundamental element of this language-game lies in Hegel's identification of the substantial being with the subject. This identity makes up an instrument or paradigm of this language-game (like Wittgenstein's measuring instrument from PI §50).

I sincerely hope that both Hegel and Wittgenstein are treated with respect in this volume. None of the authors excessively privileges one over the other, though they may express a preference. Hegel is not treated as the one who knew everything all along, nor is Wittgenstein taken as the only philosopher that can make Hegel intelligible. ${ }^{22}$ Situating Hegel in the Wittgensteinian tradition of analytic philosophy and Wittgenstein in the Hegelian tradition of German idealism may prove to be a fresh perspective in either case. In a similar way, a new perspective may consist in seeing Hegel through a Wittgensteinian lens or Wittgenstein through a Hegelian lens.

\section{References}

Baker, Gordon P. and Hacker, P. M. S.: Scepticism, Rules and Language, Blackwell, 1984. Beiser, Frederick C.: Hegel, Routledge, 2005.

Bell, Jeffrey A., Cutrofello, Andrew and Livingston, Paul M. (eds.): Beyond the Analytic-Continental Divide: Pluralist Philosophy in the Twenty-First Century, Routledge, 2016.

Brandom, Robert: Making It Explicit: Reasoning, Representing, and Discursive Commitment, Harvard University Press, 1994.

Brandom, Robert: Articulating Reasons: An Introduction to Inferentialism, Harvard University Press, 2000.

Brandom, Robert: Tales of the Mighty Dead: Historical Essays in the Metaphysics of Intentionality, Harvard University Press, 2002.

Brandom, Robert: Between Saying and Doing: Towards an Analytic Pragmatism, Oxford University Press, 2008.

Brandom, Robert: Reason in Philosophy: Animating Ideas, Harvard University Press, 2009.

Brandom, Robert: Perspectives on Pragmatism: Classical, Recent, and Contemporary, Harvard University Press, 2011.

Brandom, Robert: "Some Hegelian Ideas of Note for Contemporary Analytic Philosophy", Hegel Bulletin 35:1, 2014, pp.1-15.

Brandom, Robert: From Empiricism to Expressivism: Brandom Reads Sellars, Harvard University Press, 2015.

Carlson, David Gray (ed.): Hegel's Theory of the Subject, Palgrave Macmillan, 2005.

22 Cf. deVries (2008), who finds the same value in Redding (2007). 
Crary, Alice and Read, Rupert (eds.): The New Wittgenstein, Routledge, 2000.

deVries, Willem A.: "Review of Paul Redding, Analytic Philosophy and the Return of Hegelian Thought”, Notre Dame Philosophical Reviews 2008.04.18, URL = https://ndpr.nd.edu/ news/analytic-philosophy-and-the-return-of-hegelian-thought/, accessed 20 May 2018.

Engelmann, Paul: Letters from Ludwig Wittgenstein, with a Memoir, Blackwell, 1967.

Findlay, John N.: Hegel: A Re-Examination, Allen and Unwin, 1958.

Findlay, John N.: “Foreword”, in: Hegel's Logic. Being Part One of The Encyclopaedia of the Philosophical Sciences (1830), trans. by W. Wallace, Clarendon Press, 1973.

Findlay, John N.: Wittgenstein: A Critique, Routledge, 1984.

Floyd, Juliet: "Wittgenstein and the Inexpressible", in: Alice Crary (ed.): Wittgenstein and the Moral Life: Essays in Honor of Cora Diamond, MIT Press, pp.177-234.

Gabriel, Markus and Žižek, Slavoj: Mythology, Madness, and Laughter: Subjectivity in German Idealism, Continuum, 2009.

Gabriel, Markus: “What Kind of an Idealist (If Any) Is Hegel?”, Hegel Bulletin 37:2, 2016, pp.181-208.

Giladi, Paul: “Hegel's Metaphysics as Speculative Naturalism”, in: Allegra de Laurentiis (ed.): Hegel and Metaphysics: On Logic and Ontology in the System, de Gruyter, 2016, pp.149-162.

Henrich, Dieter: Hegel im Kontext, Suhrkamp, 1971.

Horstmann, Rolf-Peter: "Substance, Subject and Infinity: A Case Study of the Role of Logic in Hegel's System”, in: Katerina Deligiorgi (ed.): Hegel: New Directions, Acumen, 2006, pp.69-84.

Horwich, Paul: "Wittgenstein on Rules and Private Language. Saul Kripke”, Philosophy of Science 51:1, 1984, pp.163-171.

Houlgate, Stephen: An Introduction to Hegel: Freedom, Truth and History, Blackwell, 2005.

Koreň, Ladislav and Kolman, Vojtěch: “Introduction. Inferentialism's Years of Travel and Its LogicoPhilosophical Calling”, in: O. Beran, V. Kolman and L. Koreň (eds.): From Rules to Meanings: New Essays on Inferentialism, Routledge, 2018, pp.1-45.

Kripke, Saul: Wittgenstein on Rules and Private Language, Blackwell, 1982.

Lamb, David: Language and Perception in Hegel and Wittgenstein, St. Martin's Press, 1979.

Lamb, David: Hegel - From Foundation to System, Martinus Nijhoff Publishers, 1980.

Lumsden, Simon: “Hegel, Analytic Philosophy and the Return of Metaphysics", Parrhesia 11, 2011, pp.89-93.

McDowell, John: “Wittgenstein on Following a Rule”, Synthese 58, 1984, pp.325-364.

McDowell, John: Mind and World, second ed., Harvard University Press, 1996.

McDowell, John: Having the World in View: Essays on Kant, Hegel, and Sellars, Harvard University Press, 2009.

Nuzzo, Angelica (ed.): Hegel and the Analytic Tradition, Continuum, 2010.

Pinkard, Terry: Hegel's Phenomenology: The Sociality of Reason, Cambridge University Press, 1994.

Pippin, Robert: The Persistence of Subjectivity: on the Kantian Aftermath. Cambridge University Press, 2005.

Pinkard, Terry: "Hegel and Marx: Ethics and Practice", in: Roger Crisp (ed.): The Oxford Handbook of the History of Ethics, 2013, pp.505-526.

Read, Rupert and Lavery, Matthew A. (eds.): Beyond the Tractatus Wars: The New Wittgenstein Debate, Routledge, 2011. 
Redding, Paul: Analytic Philosophy and the Return of Hegelian Thought, Cambridge University Press, 2007.

Redding, Paul: “Georg Wilhelm Friedrich Hegel”, The Stanford Encyclopedia of Philosophy, E. N. Zalta (ed.), 2015, URL = https://plato.stanford.edu/archives/sum2018/entries/hegel/, accessed 20 May 2018.

Redding, Paul: “Findlay's Hegel: Idealism as Modal Actualism”, Critical Horizons: A Journal of Philosophy of Social Theory 18:4, 2017, pp.359-377.

Rockmore, Tom: "Analytic Philosophy and the Hegelian Turn", The Review of Metaphysics 55:2, 2001, pp.339-370.

Rockmore, Tom: “Some Recent Analytic 'Realist’ Readings of Hegel”, in: Nuzzo 2010: pp.158172.

Rockmore, Tom: Cognition: an Introduction to Hegel's Phenomenology of Spirit, University of California Press, 1997.

Rockmore, Tom: Hegel, Idealism and Analytic Philosophy, Yale University Press, 2005.

Rorty, Richard: “Introduction”, in: Sellars 1997: pp.1-12.

Sellars, Wilfrid: “Some Reflections of Language Games”, Philosophy of Science 21:3, 1954, pp.204-228.

Sellars, Wilfrid: Empiricism and the Philosophy of Mind, Harvard University Press, 1997.

Siep, Ludwig: Hegel's Phenomenology of Spirit, Cambridge University Press, 2014.

Stekeler-Weithofer, Pirmin: Hegels Analytische Philosophie: Die Wissenschaft der Logik als kritische Theorie der Bedeutung, Schoningh, 1992.

Stekeler-Weithofer, Pirmin: Hegel's Analytic Pragmatism, unpublished manuscript, 2016.

Stekeler-Weithofer, Pirmin: Hegels Wissenschaft der Logik. Ein dialogischer Kommentar. Band 1: Die objektive Logik. Die Lehre vom Sein, Meiner, 2019.

Stern, Robert: Routledge Philosophy Guidebook to Hegel and the Phenomenology of Spirit, Routledge, 2002.

Taylor, Charles: Hegel, Cambridge University Press, 1975.

Westphal, Kenneth R.: Hegel's Epistemology: A Philosophical Introduction to the Phenomenology of Spirit, Hackett, 2003. 
